\title{
Implementasi pendekatan pembelajaran STEM untuk meningkatkan kemampuan berpikir kritis siswa SMA pada materi gelombang bunyi
}

\author{
Nailul Khoiriyah, Abdurrahman, dan Ismu Wahyudi \\ Pendidikan Fisika, Fakultas Keguruan dan Ilmu Pendidikan, Universitas Lampung \\ J1. Prof. Dr. Soemnatri Brojonegoro No. I, Gedungmeneng Bandar Lampung 35I45 \\ Surat-e: nailulkhoiriyah.m2m@gmail.com
}

Kualitas sumber daya manusia yang rendah dipengaruhi oleh kualitas pendidikan di Indonesia yang masih tergolong rendah, sehingga perlu diterapkan pembelajaran yang membantu siswa dalam meningkatkan kemampuan berpikirnya. Penelitian ini bertujuan mengetahui implementasi pendekatan pembelajaran STEM (Science, Technology, Engineering, and Mathematics) untuk meningkatkan kemampuan berpikir kritis siswa. Sampel penelitian ini adalah siswa kelas XI MIPA I dan XI MIPA 2 SMAN I3 Bandar Lampung tahun ajaran 2017/2018. Desain penelitian ini adalah The Non-Equivalent Pretest-Posttest Control Group Design. Data kemampuan berpikir kritis siswa dikumpulkan menggunakan instrumen tes kemampuan berpikir kritis. Hasil penelitian menunjukkan bahwa nilai rata-rata $\mathrm{N}$-gain pada kelas eksperimen sebesar 0,63 dan kelas kontrol sebesar 0,35 dengan kategori sedang. Secara keseluruhan implementasi pendekatan pembelajaran STEM mampu meningkatkan kemampuan berpikir kritis siswa.

The low quality of human resources is influenced by the quality of education in Indonesia is still relatively low, so it needs to be applied learning that helps students improve their thinking ability. This study aims to determine the implementation of STEM learning approach to improve students' critical thinking skills. The sample of this research is the students of class XI MIPA I and XI MIPA 2 SMAN I3 Bandar Lampung academic year 2017/2018. The design of this study was The Non-Equivalent Pretest-Posttest Control Group Design. Students' critical thinking skills data were collected using critical critical thinking test instruments. The results showed that the average value of $\mathrm{N}$-gain in the experimental class was 0.63 and control class was 0.35 in the medium category. Overall implementation of STEM learning approach can improve students' critical thinking ability.

Kata kunci: Kemampuan berpikir kritis, Pendekatan STEM, Problem Based Learning.

\section{Pendahuluan}

Pendidikan adalah upaya yang dilakukan untuk menyiapkan siswa melalui kegiatan pembelajaran yang bertujuan untuk membantu siswa secara aktif mengembangkan potensi, kemampuan, dan bakat yang dimilikinya. Permendikbud no. 65 tahun 2013 tentang standar proses pendidikan dasar dan menengah telah menyatakan tentang pentingnya proses pembelajaran menggunakan kaidah-kaidah pendekatan saintifik/ilmiah [I]. Selaras dengan hal tersebut, Pustaka [2] menyatakan bahwa pembelajaran dalam dunia pendidikan harus mampu meningkatkan keterampilan proses dan keterampilan sosial siswa.
Pendidikan berpengaruh terhadap kualitas sumber daya manusia. Kualitas sumber daya manusia dapat dilihat dari kemampuan lulusannya yang memiliki keterampilan, menguasai teknologi, serta memiliki pengetahuan yang luas dan keahlian profesional. Kenyatannya, Indonesia sebagai negara yang memasuki era persaingan bebas masih memiliki sumber daya manusia yang rendah. Kualitas sumber daya manusia yang rendah dipengaruhi oleh kualitas pendidikan di Indonesia yang masih tergolong rendah. Kemampuan siswa dalam menjawab soal penerapan dan penalaran lebih rendah daripada soal pemahaman. Hasil ini didukung dari riset PISA (Programme for International Students Assessment) pada tahun 2015 yang terbit pada tahun 2016 yang menunjukkan bahwa Indonesia memiliki nilai rata-rata 
403 dari rata-rata internasional 500 dan 50I [3]. Data riset TIMSS (Trends in International Mathematics and Science Study) tahun 2015, Indonesia menempati urutan ke 69 dari 76 negara yang terlibat [4].

Peningkatan kualitas pendidikan di Indonesia dapat dilakukan melalui penerapan reformasi pendidikan. Perubahan yang terjadi pada pembelajaran tradisional menuju ke pembelajaran yang lebih meningkatkan daya berpikir kritis disebut dengan reformasi pendidikan [5]. Salah satu bentuk reformasi pendidikan dapat dilakukan dengan menggunakan pendekatan pembelajaran yang dapat membantu guru dalam menciptakan tenaga ahli yaitu pendekatan STEM. Pendekatan STEM ini adalah pendekatan yang merujuk kepada empat komponen ilmu pengetahuan, yaitu: pengetahuan, teknologi, teknik, dan matematika. Selaras dengan hal tersebut berdasarkan penelitian menunjukkan bahwa penerapan STEM dapat membantu mengembangkan pengetahuan, membantu menjawab pertanyaan berdasarkan penyelidikan, dan dapat membantu siswa untuk mengkreasi suatu pengetahuan baru [6].

Penerapan pendekatan pembelajaran STEM ini dapat membantu meningkatkan kemampuan berpikir kritis siswa. Berpikir kritis adalah berpikir dengan reflektif yang berfokus pada pengambilan keputusan tentang apa yang diyakini dan apa yang harus dilakukan selanjutnya [7]. Pendekatan pembelajaran STEM dengan mengintegrasikan keempat komponennya mampu menghasilkan aktivitas mental yang berguna untuk membantu memunculkan berpikir kritis siswa yang ditandai dengan kemampuan memecahkan masalah, mengambil keputusan, menganalisis asumsi, mengevaluasi, dan melakukan penyelidikan.

Berdasarkan hasil observasi yang dilakukan di SMA Negeri I3 Bandar Lampung yang dilakukan untuk mengetahui pembelajaran di kelas dapat diketahui bahwa guru mulai menggunakan pendekatan saintifik, namun lebih sering menggunakan pendekatan konvensional saja. Hasil observasi yang dilakukan dapat diketahui bahwa kemampuan siswa dalam menanggapi pertanyaan dengan alasan, mengajukan pertanyaan pada saat belum mengerti materi masih kurang, begitu pun ketika siswa diminta untuk menganalisis suatu permasalahan, menyimpulkan permasalahan, dan mengevaluasi permasalahan masih kurang. Sejalan dengan hasil dari wawancara tersebut, sebagai upaya untuk mengatasi dan meningkatkan kualitas sumber daya manusia melalui pendidikan maka diperlukan penerapan kemampuan berpikir kritis dengan menggunakan pendekatan STEM.

\section{Kajian Pustaka}

\section{Pendekatan Pembelajaran STEM (Science, Technology, Engineering, and Mathematics)}

Pendidikan STEM bermakna memberi penguatan praktis pendidikan dalam bidang-bidang STEM secara terpisah, sekaligus lebih mengembangkan pendekatan pendidikan yang mengintegrasikan sains, teknologi, rekayasa, dan matematika dengan memfokuskan proses pendidikan pada pemecahan masalah nyata dalam kehidupan sehari-hari ataupun kehidupan profesi [2].

Pendekatan STEM tidak hanya dapat diterapkan di sekolah dasar dan sekolah menengah, tapi juga dapat diterapkan di perkuliahan bahkan program doctoral. Pendekatan STEM menghubungkan pembelajaran dengan empat komponen pengajaran, yaitu science, technology, engenering, and mathematic. Selaras dengan hal tersebut pendekatan STEM dapat dilaksanakan pada tingkat pendidikan formal/di dalam kelas dan tingkat satuan non formal/di luar kelas [8].

STEM beberapa tahun terakhir ini sudah banyak diterapkan di beberapa negara seperti di Taiwan, peningkatan kurikulum 9 tahun mulai mengintegrasi pembelajaran STEM yang membuat siswa berperan sebagai pusat kegiatan belajar [9]. Pendekatan dengan menggunakan STEM dapat berupaya memunculkan keterampilan dalam diri siswa, misalnya kemampuan menyelesaikan persoalan dan kemampuan melakukan penyelidikan. Keterampilan ini penting untuk membantu meningkatkan sumber daya manusia. Berikut ini adalah tabel yang menunjukkan definisi dari literasi STEM pada empat bidang studi yang saling berhubungan [10].

Tabel I. Definisi Literasi STEM

\begin{tabular}{|c|c|c|}
\hline No & STEM & Keterangan \\
\hline $\mathrm{I}$ & $\begin{array}{l}\text { Sains } \\
\text { (Science) }\end{array}$ & $\begin{array}{l}\text { Literasi sains : kemampuan dalam } \\
\text { mengidentifikasi informasi ilmiah, lalu } \\
\text { mengaplikasikannya dalam dunia nyata } \\
\text { yanng juga mempunyai peran dalam } \\
\text { mencari solusi. }\end{array}$ \\
\hline 2 & $\begin{array}{l}\text { Teknologi } \\
\text { (Technology) }\end{array}$ & $\begin{array}{l}\text { Literasi teknologi : keterampilan dalam } \\
\text { menggunakan berbagai teknologi, belajar } \\
\text { mengembangkan teknologi, menganalisis } \\
\text { teknologi dapat mempengaruhi pemikiran } \\
\text { siswa dan masyarakat. }\end{array}$ \\
\hline 3 & $\begin{array}{l}\text { Teknik } \\
\text { (Engineering) }\end{array}$ & $\begin{array}{l}\text { Literasi desain : kemampuan dalam } \\
\text { mengembangkan teknologi dengan desain } \\
\text { yang lebih kreatif dan inovatif melalui } \\
\text { penggabungan berbagai bidang keilmuan. }\end{array}$ \\
\hline 4 & $\begin{array}{l}\text { Matematika } \\
\text { (Mathematics) }\end{array}$ & $\begin{array}{l}\text { Literasi matematika : kemampuan dalam } \\
\text { menganalisis dan menyampaikan gagasa, } \\
\text { rumusan, menyelesaikan masalah secara } \\
\text { matematik dalam pengaplikasiaanya. }\end{array}$ \\
\hline
\end{tabular}

Pustaka [II] mengembangkan tiga pendekatan pembelajaran STEM yang dapat diterapkan, yaitu: (I) Pendekatan Silo yaitu pendekatan yang menekankan pada 
kesempatan siswa untuk mendapatkan pengetahuan daripada keterampilan teknis [12], (2) Pendekatan tertanam yaitu pendekatan yang menekankan pada penguasaan pengetahun melalui keadaan dunia nyata dan cara yang dapat dilakukan untuk menyelesaikan permasalahan dalam lingkup sosial, budaya, dan fungsional. (3) Pendekatan Terpadu yaitu pendekatan ini menekankan pada penggabungan berbagai bidang STEM dan menjadikannya satu subjek.

\section{Metode Pembelajaran Problem Based Learning (PBL)}

Metode pembelajaran berbasis masalah adalah metode pembelajaran yang mampu melibatkan kemampuan metakognisi yang dimiliki siswa. Metakognisi merupakan pengetahuan mengenai kemampuan kognitif diri sendiri. Proses metakognisis akan muncul pada tahap orientasi masalah yang aktual dan autentik [13]. Tahap ini siswa akan diajak untuk mengumpulkan informasi dan fakta yang berfungsi untuk memfokuskan terhadap apa yang dibutuhkan untuk memecahkan masalah, kemudian menghubungkannya dengan hipotesis yang dibuat dan melakukan uji hipotesis.

PBL adalah metode dalam pembelajaran yang dimana siswa membentuk kelompok-kelompok kecil yang kemudian bertugas untuk menyelesaikan permasalahan dengan melibatkan berbagai komponen misalnya complex, open-ended, dan reals life problems bersama anggota kelompok [I4]. PBL adalah salah satu metode pembelajaran yang dapat menantang siswa untuk mencari solusi suatu masalah dari dunia nyata yang dapat diselesaikan dengan cara berkelompok. PBL mengarahkan siswa untuk belajar mandiri sehingga dapat mengembangkan keterampilan berpikir kritis dan dapat menganalisis masalah yang di dunia nyata [I5].

Berdasarkan beberapa pendapat tersebut dapat disimpulkan bahwa PBL lebih menekankan pada kemampuan siswa dalam membangun pengetahuannya sendiri, dimana siswa menjadi pusat kelas (student center) dan guru sebagai pembimbing. Metode PBL tersebut dengan demikian dapat membantu siswa dalam meningkatkan kemampuan berpikir kritis siswa yang mana metode ini memiliki sifat membangun pengetahuan, sehingga siswa tidak langsung mendapatkan informasi tetapi siswa harus berupaya dengan mengorientasi, memecahkan masalah, mengevaluasi dan mengambil keputusan dari masalah.

Menurut penelitian yang dilakukan oleh Akinoglu dan Ruhan [16], menyatakan bahwa dalam metode PBL terdapat beberapa sikap yang dihasilkan oleh siswa yaitu mempunyai rasa ingin tahu yang tinggi untuk memecahkan masalah, meningkatkan kemampuan siswa berpikir sehingga tidak hanya menerima informasi secara langsung, kemampuan dalam menjalin kerjasama dalam kelompok, dapat berkomunikasi dengan baik, dan akhirnya informasi dapat berkembang secara positif.

\section{Berpikir Kritis}

Pembelajaran yang mendorong siswa mengembangkan gagasan melalui langkah khusus dengan memanipulasi pengetahuan yang didapat yang menghasilkan pengetahuan baru disebut dengan kemampuan berpikir tingkat tinggi atau Higher Order Thinking Skill (HOTS) [17]. Kemampuan ini dapat diraih ketika siswa mampu menghubungkan berbagai informasi atau pengetahuan yang didapat dari informasi yang telah ada sebelumnya untuk selanjutnya dikembangkan dengan memecahkan kesimpulan dari informasi tersebut [18].

Berpikir menggunakan kemampuan menganalisis informasi, memberikan pendapat dengan disertai bukti yang mendukung, tidak berpikiran sempit, dan melakukan penyelidikan atas informasi baru yang diperoleh disebut dengan kemampuan berpikir kritis. Pada dasarnya orang yang berpikir kritis tersebut tidak langsung menerima atau menolak informasi tapi siswa tersebut menggunakan pemikiran kognitif untuk memperoleh kebenaran informasi [19]. Menurut pustaka [7] terdapat beberapa komponen yang dapat menunjukkan kemampuan berpikir kritis siswa: (I) memberikan klarifikasi dasar terkait permasalahan. (2) mengumpulkan informasi dasar. (3) memberikan pendapat dan kesimpulan awal. (4) membuat klarifikasi lebih lanjut. (5) menarik kesimpulan yang terbaik.

Kemampuan berpikir kritis tersebut dapat dijelaskan sebagai berikut: (I) Pembelajaran dengan menerapakan kemampuan berpikir kritis menuntut siswa untuk mampu menjabarkan, mengeneralisasi, menyimpulkan secara deduktif, serta mampu menentukan cara yang tepat. (2) Pembelajaran dengan menggunakan kemampuan berpikir kritis menuntut siswa untuk dapat menyelesaikan suatu masalah. (3) Kemampuan berpikir kritis menuntut siswa untuk mampu memahami tentang bagaimana siswa dapat mengetahui gagasan yang muncul, menyadari ketika membutuhkan pengetahuan yang baru, serta mampu menentukan langkah-langkah yang akan digunakan untuk menyelesaikan suatu permasalahan, sehingga dapat dengan mudah untuk mengumpulkan dan mempelajari pengetahuan tersebut[4]. Pembelajaran dengan menerapkan kemampuan berpikir kritis siswa berarti dalam pembelajaran tersebut penilaian dilakukan dengan fair dan objective [20].

Pembelajaran yang mencirikan penerapan kemampuan berpikir kritis yaitu pembelajaran yang memberikan kesempatan kepada siswa untuk turut berperan aktif (student center), dengan mendorong siswa untuk mampu mengidentifikasi kemungkinan solusi yang ada, selanjutnya mampu memilah data dari informasi yang didapatkan, kemudian mampu memberikan pendapat 
tentang data yang dipilih, yang digunakan untuk menyusun jawaban sementara dan akhirnya mampu memberikan kemungkinan penyelesaian masalah [2I].

Pembelajaran yang menggunakan pemikiran reflektif dan produktif dalam membahas suatu permasalahan dengan mengikutsertakan pemberian bukti disebut pemikiran kritis. Berpikir kritis juga merupakan proses berpikir yang berfungsi untuk mengidentifikasi masalah sampai pada menemukan solusi dari masalah tersebut. Berpikir kritis juga dapat menghasilkan sebuah keputusan atau pertimbangan yang diolah dengan logis dalam memecahkan permasalahaan [22].

\section{Pemetaan Materi Gelombang Bunyi}

Tabel 2. Pemetaan materi yang terintegrasi

\begin{tabular}{|c|c|}
\hline $\begin{array}{l}\text { No } \\
\text { (I) }\end{array}$ & $\begin{array}{l}\text { STEM } \\
(2)\end{array}$ \\
\hline $\mathrm{I}$ & $\begin{array}{l}\text { Science } \\
\text { a. Melakukan pengamatan terhadap fungsi dan kegunaan sound dalam } \\
\text { kehidupan sehari-hari, kemudian mengindentifikasi apakah terdapat } \\
\text { karateristik dari gelombang bunyi dan juga berlakunya persamaan cepat } \\
\text { rambat gelombang bunyi. }\end{array}$ \\
\hline & $\begin{array}{l}\text { b. Melakukan pengamatan terhadap fungsi dan kegunaan sound dalam } \\
\text { kehidupan sehari-hari, sehingga dapat mengumpulkan informasi apakah } \\
\text { berlaku konsep gelombang bunyi (Efek Doppler). } \\
\text { c. Melakukan percobaan dengan menggunakan phet simulation untuk } \\
\text { menentukan keberlakukan hubungan cepat rambat gelombang bunyi } \\
\text { pada suatu benda. }\end{array}$ \\
\hline 2 & $\begin{array}{l}\text { Technology } \\
\text { Teknologi sebagai penerapan sains. } \\
\text { a. Mengamati teknologi sains yaitu sound serta menemukan fenomena } \\
\text { yang berkaitan dengan penerapan konsep fisika pada gelombang bunyi } \\
\text { (sound) pada SONAR pada kapal laut. } \\
\text { b. Menganalisis bagaimana bunyi dapat terdengar dengan menggunakan } \\
\text { sound dan bagaimana bunyi tersebut dapat terdengar dengan jarak yang } \\
\text { cukup jauh. }\end{array}$ \\
\hline
\end{tabular}

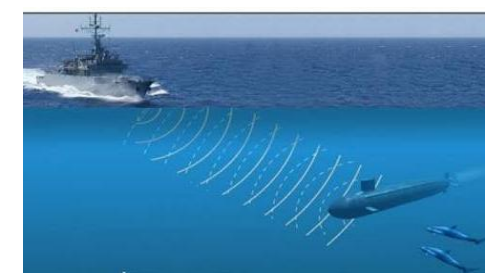

Gambar I. SONAR Mendeteksi Kapal Laut

Sumber: https://thiflihabibi.wordpres.com [27]

Engineering sebagai Rekayasa Sains

a. Memecahkan masalah dengan memberikan solusi berkenaan dengan teknologi sound yaitu teknik untuk merekayasa

b. pemasangan klakson mobil yang berfungsi untuk memberitahukan kepada pengendara lain keberadaan mobil tersebut.

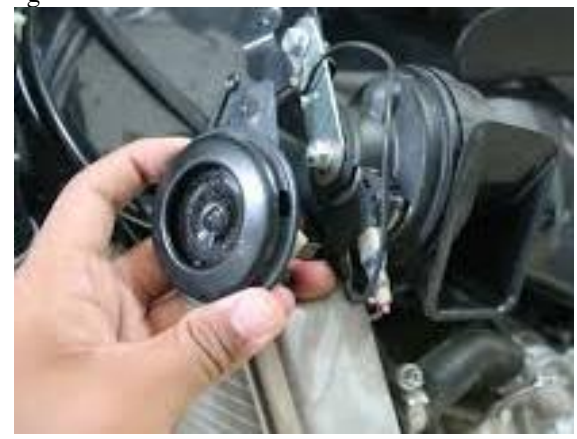

Gambar 2. Klakson pada mobil

Sunber: https: \\fachruldeanca.wordpress.com [28]

Memberikan pendapat, membuat klarifikasi awal, membuat klarifikasi lebih lanjut.

a. Menganalisis penerapan sound dengan menggunakan video pembelajaran.

b. Memberikan pendapatnya setelah melakukan peng-amatan terhadap video pembelajaran yang diberi-kan.

c. Menganalisis penerapan taraf intensitas bunyi dalam kehidupan sehari-hari.

Membuat klarifikasi awal, membuat klarifikasi lanjut.

a. Mengidentifikasi macam-macam pengeras suara dalam yang diterapkan dalam kehidupan sehari-hari.

b. Menganalisis penggunaan pengeras suara tersbut dalam kehidupan sehari-hari.

c. Menganalisis penerapan Efek Doppler dalam penggunaan pengeras suara tersebut dalam kehidupan sehari-hari. 


\begin{tabular}{|c|c|c|}
\hline $\begin{array}{l}\text { No } \\
\text { (I) }\end{array}$ & $\begin{array}{l}\text { STEM } \\
\text { (2) }\end{array}$ & $\begin{array}{c}\text { Berpikir Kritis } \\
\text { (3) }\end{array}$ \\
\hline 4 & $\begin{array}{l}\text { Mathematics } \\
\text { Matematika sebagai Alat } \\
\text { a. Melakukan pengamatan terhadap fungsi dan kegunaan sound dalam } \\
\text { kehidupan sehari-hari, sehingga dapat dianalisis keberlakuan gelombang } \\
\text { bunyi melalui karakteristiknya dan } \\
\text { b. merumuskan persamaan cepat rambat gelombang bunyi. } \\
\text { c. Melakukan percobaan tentang penerapan gelombang bunyi yaitu sound } \\
\text { atau klakson pada mobil, sehingga dapat menganalisis keberlakuan Efek } \\
\text { Doppler dalam kehidupan sehari-hari. } \\
\text { d. Melakukan pengamatan tentang Gelombang Stasioner pada alat } \\
\text { penghasil bunyi. }\end{array}$ & $\begin{array}{l}\text { Membuat klarifikasi awal, membuat klarifikasi lanjut, } \\
\text { menyampaikan pendapat, dan membuat kesimpulan. } \\
\text { a. Menganalisis karakteristik gelombang bunyi dan } \\
\text { persamaan. } \\
\text { b. yang berlaku pada gelombang bunyi. } \\
\text { c. Menerapkan persamaan Efek Doppler dalam me- } \\
\text { mecahkan permasalahan pada penggunaan sound atau } \\
\text { klakson pada mobil dalam kehidupan sehari-hari. } \\
\text { d. Menerapkan persamaan yang berlaku pada gelombang } \\
\text { stasioner pada pipa organa terbuka dan pipa organa } \\
\text { tertutup. } \\
\text { e. Memberikan pendapat dari hasil percobaan dan } \\
\text { menyimpulkan percobaan Efek Doppler dan gelombang } \\
\text { stasioner. }\end{array}$ \\
\hline
\end{tabular}

\section{Metode Penelitian}

Penelitian ini merupakan penelitian eksperimen. Populasi dalam penelitian ini adalah seluruh siswa kelas XI MIPA SMA Negeri 13 Bandar Lampung yang sedang menempuh semester genap Tahun Pelajaran 2017/2018 dengan jumlah lima kelas yang terdiri dari I50 siswa. Penelitian ini akan menggunakan dua kelas sebagai sampel dengan teknik purposive sampling. Kedua kelas yang telah dipilih sebagai sampel, selanjutnya akan dibagi menjadi kelas eksperimen dan kelas kontrol. Kelas eksperimen akan menggunakan pendekatan (STEM) dan kelas kontrol akan menggunakan pendekatan pembelajaran yang biasa digunakan oleh guru (pendekatan konvensional).

Dalam penelitian ini terdapat tiga variabel, yaitu variabel bebas, variabel terikat, dan variabel moderator. Variabel bebasnya adalah pendekatan pembelajaran STEM, variabel terikatnya adalah berpikir kritis, dan variabel moderatornya metode PBL.

Desain penelitian yang diterapkan pada penelitian ini adalah quasi-experiment design dan menggunakan jenis eksperimen the non-equivalent pretest-postest control group design [23]. Pengambilan subjek secara random pada kelas ekperimen dan kelas kontrol. Pengambilan subjek secara random pada kelas ekperimen dan kelas kontrol.

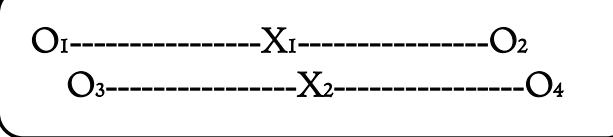

Gambar 3. The non-equivalent pretest-posttest control group design

Keterangan:

$\mathrm{O}_{\mathrm{I}}=$ Pretest pada kelas eksperimen

$\mathrm{O}_{2}=$ Posttest pada kelas eksperimen

$\mathrm{O}_{3}=$ Pretest pada kelas kontrol

$\mathrm{O}_{4}=$ Posttest pada kelas kontrol

$\mathrm{X}_{\mathrm{I}}=$ menggunakan pendekatan pembelajaran STEM

$\mathrm{X}_{2}=$ tanpa menggunakan pendekatan pembelajaran STEM.
Pengumpulan data dilakukan dengan menggunakan tes hasil belajar yang terdiri dari IO soal pilihan jamak beralasan dan 5 soal esai yang mengacu pada kemampuan berpikir kritis. Instrumen yang diberikan kepada siswa adalah instrumen yang sudah diuji validitas dan reliabilitasnya yang berupa soal pretest dan posttest. Soal pretest untuk mengetahui tingkat kemampuan awal siswa dan digunakan untuk danya perubahan, sedangkan soal posttest digunakan untuk menunjukkan berapa besar perubahan yang dihasilkan setelah perlakukan.

Data yang diperoleh selanjutnya diuji analisis data hasil penelitian dan uji hipotesis untuk mengetahui apakah hipotesis penelitian diterima atau ditolak. Uji hipotesis dilakukan dengan menggunakan skor dan nilai pretest dan posttest yang menggunakan kriteria penilaian pustaka [7]. Menganalisis data hasil pembelajaran menggunakan

\section{$\mathrm{N}$-gain}

Analisis $N$-Gain adalah analisis selisih nilai yang dapat menunjukkan perbedaan pengetahuan siswa di awal dan di akhir pembelajaran pada kelas eksperimen dan kelas kontrol [24]. Rumus $\mathrm{N}$-Gain adalah sebagai berikut:

$$
N-G \text { ain }(\mathrm{g})=\frac{\text { nilai posttest- nilai pretest }}{\text { skor maksima ideal - nilai prestest }}
$$

Kriteria interpretasi $N$-Gain adalah sebagai berikut:

Tabel 3. Kriteria Interpretasi N-Gain

\begin{tabular}{ll}
\hline$N$-Gain & Kriteria Interpretasi \\
\hline$N$-gain $>0,7$ & Tinggi \\
$0,3 \leq N$-gain $\leq 0,7$ & Sedang \\
$N$-gain $<0,3$ & Rendah \\
\hline
\end{tabular}




\section{Uji Normalitas}

Dalam penelitian ini digunakan uji normalitas untuk mengetahui sampel dari populasi tersebut berdistribusi normal atau tidak. Data yang termasuk terdistribusi normal apabila $x^{2}$ hitung $\leq x^{2}$ tabel dengan $d k=k$ dengan taraf signifikasi 5\% [25]. Rumus Hipotesis:

$\mathrm{H}_{0}$ : data berdistribusi normal

$\mathrm{H}_{\mathrm{I}}:$ data tidak berdistribusi normal

\section{Uji Homogenitas}

Penelitian ini menggunakan uji homogenitas 2 varians untuk mengetahui data hasil belajar siswa pada kedua kelas sampel mempunyai varians yang homogen atau tidak [25]. Kriteria ujinya adalah terima $\mathrm{H}_{\circ}$ jika $F_{\text {hitung }}<F_{\text {tabel }}$ dan tolak jika sebaliknya. Rumusan hipotesis

$\mathrm{H}_{0}$ : (terdapat varians yang homogen dalam data hasil belajar siswa)

$\mathrm{H}_{\mathrm{I}}$ : (terdapat varians yang tidak homogen pada hasil belajar)

\section{Uji Independent Sample T-test}

Pustaka [26] menyatakan analisis Independent Sample T-Test ini digunakan untuk mengetahui ada atau tidaknya perbedaan rata-rata antara dua kelompok sampel yang tidak berhubungan. Kriteria uji $\mathrm{H}_{\circ}$ diterima jika $t_{\text {hitung }}<F_{(1-\alpha)}$ dan akan ditolak jika sebaliknya, dengan menggunakan derajat kebebasan $d k=n_{1}+n_{2}-2$ dan peluangnya sebesar $(1-\alpha)$ dengan taraf signifikasi $\alpha=5 \%=5 \%$. Rumusan hipotesis

$\mathrm{H}_{\mathrm{o}}$ : (tidak terdapat perbedaan rata-rata kemampuan berpikir kritis siswa dengan menggunakan pendekatan pembelajaran STEM).

$\mathrm{H}_{\mathrm{I}}$ : (terdapat perbedaan rata-rata kemampuan berpikir kritis siswa dengan menggunakan pendekatan pembelajaran STEM).

\section{Uji Paired sample T-test}

Paired sample $T$-test digunakan untuk mengetahui peningkatan sebelum dan setelah dilakukan pembelajaran. Kriteria ujinya terima $\mathrm{H}_{\mathrm{I}}$ jika nilai probabilitas (Asym. Sig) $<0,05$ dan sebaliknya [25]. Hipotesisnya adalah: $\mathrm{H}_{0}$ : (tidak terdapat peningkatan rata-rata kemampuan berpikir kritis siswa dengan menggunakan pendekatan pembelajaran STEM).
$\mathrm{H}_{\mathrm{I}}$ : (terdapat peningkatan rata-rata kemampuan berpikir kritis siswa dengan menggunakan pendekatan pembelajaran STEM.

\section{Hasil Penelitian dan Pembahasan}

Metode penelitian ini menggunakan metode PBL dan disesuaikan dengan tahapan pada pendekatan STEM yaitu memberikan pengetahuan tentang gelombang bunyi dengan memberikan apersepsi gelombang bunyi dalam kehidupan sehari-hari misalnya untuk menunjukkan gelombang bunyi merambat dengan memegang tenggorokan ketika berbicara atau berteriak. Tahap selanjutnya memberikan teknologi dari gelombang bunyi yaitu SONAR yang menggunakan karakteristik gelombang bunyi yaitu pemantulan yang biasanya digunakan untuk mendeteksi kapal selam, dan kumpulan ikan. Pada tahap selanjutnya, rekayasa pada gelombang bunyi yaitu klakson pada berbagai kendaraan yang digunakan untuk memberikan isyarat pada kedaraan lain. Tahapan matematis adalah tahap di mana siswa dibimbing untuk mampu mennetukan hubungan antara panjang gelombang bunyi dan frekuensi gelombang bunyi.

Pada kelas kontrol menggunakan pembelajaran yang biasa diterapkan oleh guru di sekolah. Proses pembelajaran yang dilakukan oleh guru menggunakan pendekatan pembelajaran saintifik, di mana siswa diberi kesempatan untuk mencari dan mengolah informasi yang diperolehnya secara mandiri.

Pada kelas eksperimen dan kelas kontrol, sebelum pembelajaran diberikan soal pretest dan setelah pembelajaran diberikan soal posttest. Instrumen yang diujikan telah diuji dan dinyatakan valid dan reliabel. Tabel 4 dan Tabel 5 menunjukkan hasil nilai pretest dan posttest kelas eksperimen dan kelas kontrol.

Tabel 4. Data Rata-rata hasil Pretest Siswa

\begin{tabular}{cccc}
\hline No & Parameter & $\begin{array}{c}\text { Pretest } \\
\text { Kelas Eksperimen }\end{array}$ & $\begin{array}{c}\text { Pretest } \\
\text { Kelas Kontrol }\end{array}$ \\
\hline I & Jumlah siswa & 30 & 30 \\
2 & Nilai terendah & 7 & 7 \\
3 & Nilai tertinggi & 37 & 25 \\
4 & Rata-rata nilai & 19 & 16 \\
\hline & Rata-rata skor & 9,63 & II,33 \\
\hline
\end{tabular}

Tabel 7. Data Rata-rata Hasil Posttest Siswa

\begin{tabular}{cccc}
\hline No & Parameter & $\begin{array}{c}\text { Prosttest } \\
\text { Kelas Eksperimen }\end{array}$ & $\begin{array}{c}\text { Posttest } \\
\text { Kelas Kontrol }\end{array}$ \\
\hline I & Jumlah siswa & 30 & 30 \\
2 & Nilai terendah & 53 & 30 \\
3 & Nilai tertinggi & 83 & 62 \\
4 & Rata-rata nilai & 70 & 46 \\
\hline & Rata-rata skor & $\mathbf{4 I , 7 3}$ & $\mathbf{2 7 , 4 3}$ \\
\hline
\end{tabular}


Implementasi pendekatan pembelajaran STEM untuk meningkatkan kemampuan berpikir kritis siswa SMA pada materi gelombang bunyi

Berdasarkan data tabel 6 rata-rata nilai pretest kelas kontrol lebih besar dari rata-rata nilai pretest kelas eksperimen. Berdasarkan data tabel 7 rata-rata nilai posttest kelas eksperimen lebih besar daripada rata-rata nilai posttest kelas kontrol.

Pada kelas kontrol rata-rata kemampuan berpikir kritis sebelum diterapkan pembelajaran dengan menggunakan pendekatan pembelajaran yang biasanya digunakan oleh guru hanya sebesar II,33, dan setelah diterapkan pendekatan yang biasa dilakukan oleh guru rata-rata kemampuan berpikir kritis siswa meningkat menjadi 27,43. Hasil ini menunjukkan adanya peningkatan kemampuan berpikir kritis siswa sebesar I6,I0 setelah diterapkan pendekatan pembelajaran yang biasa digunakan oleh guru dengan kategori peningkatan sedang. Pada kelas eksperimen, rata-rata kemampuan berpikir kritis siswa sebelum diterapkannya pendekatan pembelajaran STEM sebesar 9,63, dan setelah diterapkan pendekatan pembelajaran STEM rata-rata kemampuan berpikir kritis siswa meningkat menjadi 4I,73. Hasil ini menunjukkan adanya peningkatan kemampuan berpikir kritis siswa sebesar 32,10 setelah diterapkannya pembelajaran dengan menggunakan pendekatan pembelajaran STEM dengan I8 siswa memiliki kategori tinggi dan 12 siswa memiliki kategori sedang.

Tabel 8. Rata-rata N-gain Kemampuan Berpikir Kritis

\begin{tabular}{ccc}
\hline Perolehan Skor & Kelas Eksperimen & Kelas Kontrol \\
\hline Gain Tertinggi & 46 & 37 \\
Gain Terendah & 46 & 23 \\
Rata-rata Gain & 50,73 & 30 \\
Kenaikan Skor & $51 \%$ & $30 \%$ \\
rata-rata & 0,63 & 0,35 \\
Rata-rata $N$-gain & Sedang & Sedang \\
Kategori &
\end{tabular}

Hasil pengujian $N$-gain berdasarkan Tabel 8 di atas diperoleh bahwa rata-rata $N$-gain kelas eksperimen sebesar 0,63 dengan kategori sedang, di mana kemampuan berpikir kritis siswa dijabarkan sebagai berikut 9 siswa memperoleh kategori tinggi dan 2 I siswa memperoleh kategori sedang. Rata-rata $N$-gain kelas kontrol sebesar 0,35 dengan kategori sedang, di mana kemampuan berpikir kritis siswa dijabarkan sebagai berikut 2I siswa memperoleh kategori sedang dan 9 siswa memperoleh kategori rendah. Hasil ini menunjukkan bahwa rata-rata kemampuan berpikir kritis siswa sebelum dan setelah diterapkannya pembelajaran menggunakan pendekatan pembelajaran STEM dan pembelajaran dengan pendekatan yang biasa dipakai oleh guru berada pada kategori sedang.
Tabel 9. Hasil Uji Normalitas Data N-Gain

\begin{tabular}{clcccc}
\hline \multirow{2}{*}{ No } & \multirow{2}{*}{ Parameter } & \multicolumn{2}{c}{ Kelas Eksperimen } & \multicolumn{2}{c}{ Kelas Kontrol } \\
& Pretest & Posttest & Pretest & Posttest \\
\hline I & Jumlah Siswa & 30 & 30 & 30 & 30 \\
2 & $\begin{array}{l}\text { Rata-rata } \\
\text { Skor }\end{array}$ & 19 & 70 & 16 & 46 \\
3 & $\begin{array}{l}\text { Nilai } \\
\text { Tertinggi }\end{array}$ & 37 & 83 & 25 & 62 \\
4 & $\begin{array}{l}\text { Nilai } \\
\text { Terendah }\end{array}$ & 7 & 53 & 7 & 30 \\
5 & $\begin{array}{l}\text { N-gain } \\
\text { Asymp. Sig }\end{array}$ & \multicolumn{2}{c}{0,63} & \multicolumn{2}{c}{0,35} \\
(2-tailed) & \multicolumn{2}{c}{0,492} & \multicolumn{2}{c}{0,894} \\
\hline
\end{tabular}

Hasil uji $N$-gain kemudian digunakan untuk menguji normalitas data $N$-gain. Hasil uji normalitas berdasarkan Tabel 4 di atas menunjukkan pada kelas kontrol 0,894 dan pada kelas eksperimen 0,492 yang memiliki distribusi normal. Hasil uji $N$-gain, selanjutnya digunakan untuk menguji homogenitas kelas kontrol dan kelas eksperimen dengan nilai sig. sebesar 0,965 yang memiliki varian yang sama.

Tabel I0. Hasil Uji Homogenitas

\begin{tabular}{rccc}
\hline $\begin{array}{c}\text { Levene } \\
\text { Statistic }\end{array}$ & $d f 1$ & $d f 2$ & Sig. \\
\hline 0,002 & I & 58 & 0.965 \\
\hline
\end{tabular}

Tabel II. Hasil Uji Independent Sample T-test

\begin{tabular}{lcc}
\hline Data & Keterangan & $\begin{array}{l}\text { Gain } \\
\text { Equal Variances } \\
\text { Assumed }\end{array}$ \\
\hline $\begin{array}{lcc}\text { t-test for Equality of } \\
\text { Means }\end{array}$ & $\mathrm{T}$ & 9,918 \\
& $\mathrm{Df}$ & 58 \\
& Sig (2-tailed) & 0,000 \\
\hline
\end{tabular}

Uji hipotesis diperoleh dari metode eksperimen yang menggunakan data penelitian dan dilakukan setelah uji Independent Sample T-test untuk mengetahui perbedaan kemampuan berpikir kritis kedua kelas dan uji Paired Sample T-test untuk mengetahui peningkatan kemampuan berpikir kritis kelas eksperimen setelah menerapkan pendekatan pembelajaran STEM. Uji Independent Sample T-test menyatakan $\mathrm{H}_{\mathrm{I}}$ diterima yang dapat dilihat dari nilai thitung yaitu 9,9I8 dan signifikasi dari tabel tersebut adalah 0,000 yang berarti terdapat perbedaan kemampuan berpikir kritis siswa pada pembelajaran menggunakan pendekatan pembelajaran STEM dengan pembelajaran yang dilakukan di kelas kontrol. Uji Paired Sample T-test menyatakan $\mathrm{H}_{\mathrm{I}}$ diterima yang dapat dilihat dari nilai thitung sebesar 27,I32 dan signifikasi dari tabel tersebut adalah 0,000 yaang berarti terdapat peningkatan kemampuan berpikir kritis dengan menerapkan pendekatan pembelajaran STEM. 
Peningkatan kemampuan berpikir kritis siswa dapat dilihat dari peningkatan setiap indikatornya pada saat diberikan soal pretest dan posttest yang secara umumnya kedua kelas mengalami peningkatan. Peningkatan tertinggi terdapat pada indikator memberikan pendapat dan kesimpulan awal, pada kelas eksperimen sebesar 21\% dan kelas kontrol sebesar 15\%. Peningkatan pada indikator ini disebabkan pendekatan STEM siswa diberikan kesempatan untuk berperan aktif dalam pembelajaran dengan memberikan pendapat dan membuat kesimpulan awal dari materi yang disampaikan. Peningkatan terendah terdapat pada indikator menarik kesimpulan.

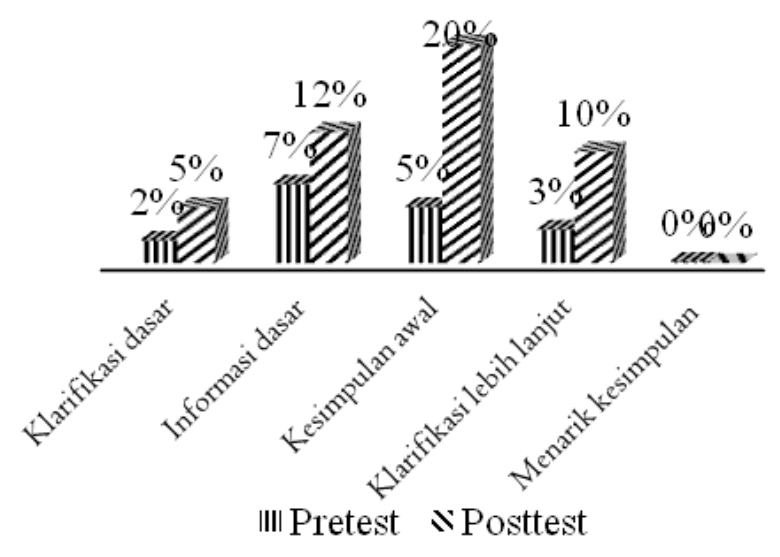

Gambar 4. Peningkatan Indikator Kemampuan Berpikir Kritis Kelas Kontrol.

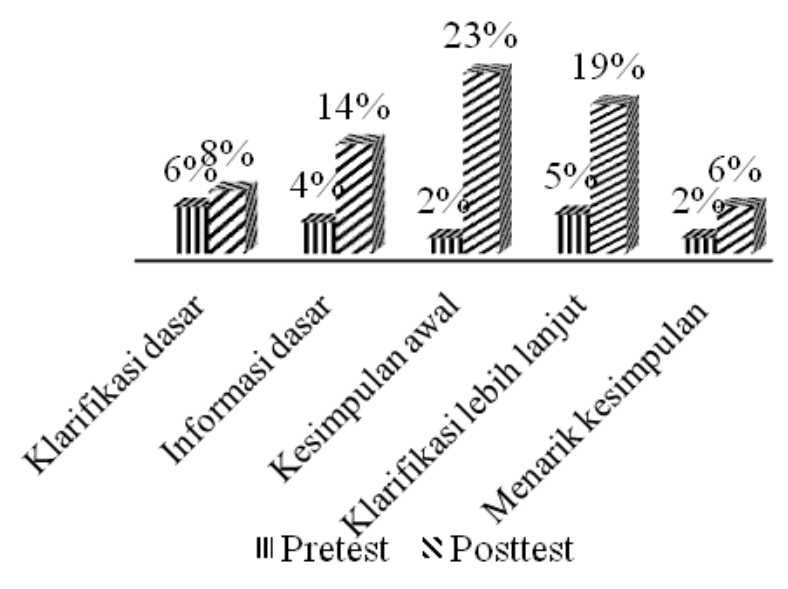

Gambar 5. Peningkatan Indikator Kemampuan Berpikir Kritis Kelas Eksperimen.

Perbedaan peningkatan kemampuan berpikir kritis masing-masing kelas dapat dilihat dari pendekatan dan proses pembelajaran pada masing-masing kelas. Pada kelas eksperimen pembelajaran dengan menggunakan pendekatan pembelajaran STEM, proses pembelajaran berlangsung lebih efektif dan aktif dalam menumbuhkan kemampuan berpikir kritis siswa jika dibandingkan dengan pembelajaran yang biasa dilakukan oleh guru di
Implementasi pendekatan pembelajaran STEM untuk meningkatkan kemampuan berpikir kritis siswa SMA pada materi gelombang bunyi

dalam kelas. Pembelajaran yang aktif terjadi ketika siswa menjadi pusat pembelajaran, melalui implementasi pendekatan pembelajaran STEM siswa dibimbing untuk menemukan sendiri jawaban atas materi yang diajarkan, sehingga siswa terlibat aktif dalam pembelajaran. Selaras dengan penelitian yang dilakukan oleh [2I] yang menyatakan bahwa kemampuan berpikir kritis dapat tumbuh dengan melibatkan siswa scara aktif (student center). Hasil ini juga didukung dengan penelitian yang dilakukan oleh pustaka [9] yang menyatakan bahwa mengintegrasikan pembelajaran STEM membuat siswa berperan sebagai pusat kegiatan belajar.

Siswa di kelas eksperimen dibimbing untuk mengamati, menanya, mencoba, mengorganisasikan, dan mengomunikasikan hasil dari sebuah fenomena yang terjadi dalam kehidupan sehari-hari (Sciences sebagai proses). Tahap selanjutnya siswa diberikan video tentang aplikasi fisika dalam kehidupan sehari-hari yang berhubungan dengan materi yang akan disampaikan yang bertujuan untuk mempermudah siswa dalam memahami materi yang dipelajari (Technology sebagai penerapan Sains). Pada tahap ini siswa mulai mengembangkan kemampuan berpikir kritisnya dengan mengidentifikasi kemungkinan jawaban yang diperoleh dan menentukan langkah-langkah yang akan digunakan untuk menyelesaikan suatu permasalahan, hal ini selaras dengan penelitian yang dilakukan oleh pustaka [20] yang menyatakan kemampuan berpikir kritis dapat muncul ketika siswa mampu mengidentifikasi dan menentukan langkah-langkah dalam penyelesaian penelitian.

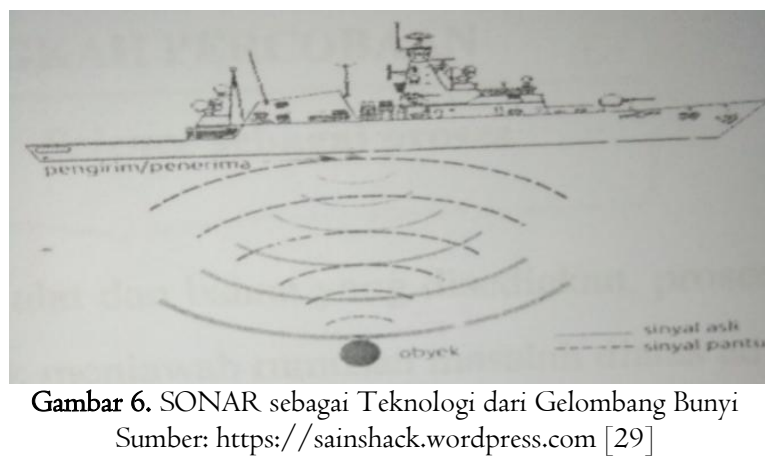

Siswa juga diberikan gambaran lebih luas dengan menggunakan pengembangan dari teknologi yang dijelaskan yang merupakan desain teknik perekayasaan (Engineering sebagai rekayasa sains). Selaras dengan penelitian yang dilakukan oleh pustaka [IO] yang menyatakan bahwa pendekatan STEM berupaya memunculkan keterampilan dalam diri siswa, misalnya dalam kemampuan menyelesaikan permasalahan dan melakukan penyelidikan yang terbagi dalam empat bidang studi yang saling berhubungan. 


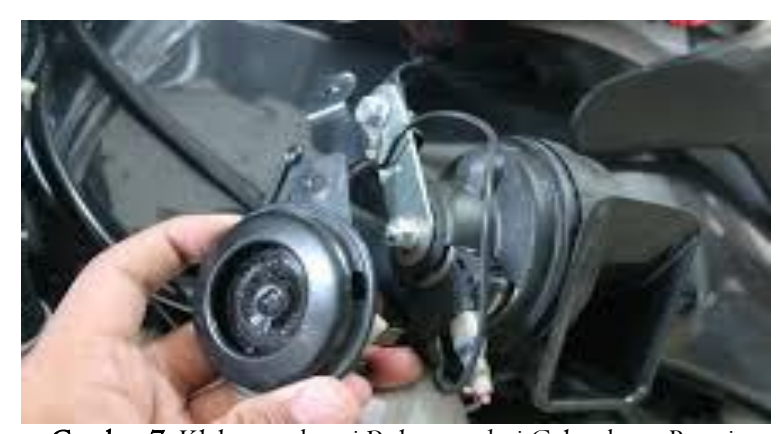

Gambar 7. Klakson sebagai Rekayasa dari Gelombang Bunyi Sunber: https: \\fachruldeanca.wordpress.com [28]

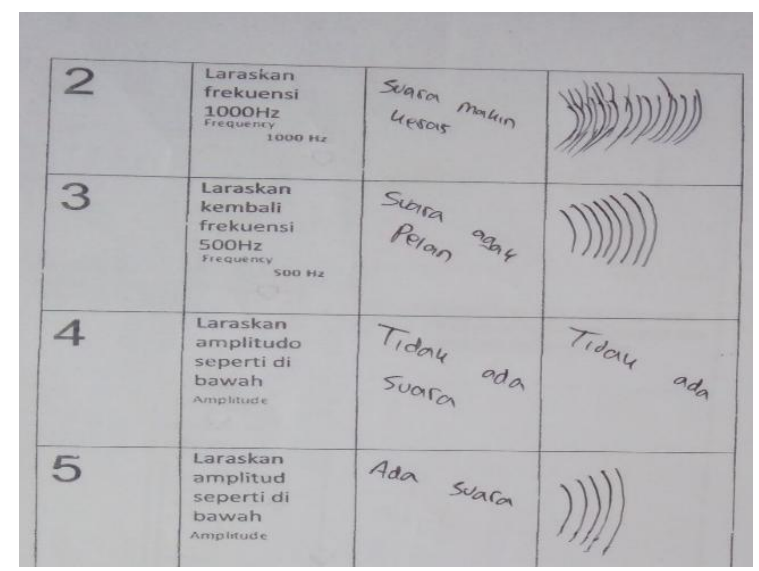

Gambar 8. Perambatan gelombang bunyi terhadap besarnya frekuensi. Sumber: foto pribadi

Tahap akhir siswa diarahkan untuk merumuskan persamaan matematis dari materi yang telah diajarkan (Mathematics sebagai alat). Siswa menemukan pengetahuan baru dalam tahap ini dengan menggunakan pengetahuan yang telah diperoleh selama pembelajaran, sehingga dari pembelajaran siswa memecahkan masalah. Pendapat ini didukung dengan penelitian yang dilakukan oleh pustaka [I8] yang menyatakan bahwa pengetahuan yang diperoleh sebelumnya dapat dikembangkan untuk memecahkan kesimpulan.

Siswa pada kelas kontrol menggunakan pendekatan pembelajaran yang biasa digunakan oleh guru kelas. Siswa hanya dibimbing untuk mengamati, menanya, mencoba, mengorganisasikan, dan mengomunikasikan hanya pada tahap proses sains saja. Pembelajaran di kelas kontrol tidak menunjukkan teknologi dan juga rekayasa dari materi yang dipelajari, sehingga siswa kurang mampu menalar dan mengembangkan kemampuan berpikir kritisnya. Selaras dengan penelitian yang dilakukan oleh pustaka [20] yang menyatakan bahwa pembelajaran yang tidak menggunakan aplikasi fisika (teknologi) dalam kehidupan sehari-hari, kurang mampu menumbuhkan kemampuan berpikir kritis siswa.

Pembelajaran dengan menggunakan pendekatan STEM pada penelitian ini dapat dikatakan memiliki keunggulan untuk meningkatkan kemampuan berpikir kritis siswa, hal ini dapat dilihat dari uji-uji yang dilakukan terhadap nilai pretest dan posttest yang mengalami peningkatan yang
Implementasi pendekatan pembelajaran STEM untuk meningkatkan kemampuan berpikir kritis siswa SMA pada materi gelombang bunyi

sigifikan. Disisi lain, secara kategori tingkat kemampuan berpikir kritis siswa masih tergolong sedang dan belum mencapai kategori tinggi, hal ini diduga karena siswa belum terbiasa belajar dengan menggunakan teknologi dan rekayasa dari materi yang dibelajarkan. Pada proses pembelajaran selama ini, siswa hanya sampai pada tahap pengetahuan dan matematis yaitu dengan mempresentasikan materi yang terdapat di buku panduan. Faktor lain yang diduga menjadi penyebab dari kurang maksimalnya peningkatan kemampuan berpikir kritis adalah motivasi intrinsik setiap siswa yang berbeda-beda. Siswa dengan motivasi intrinsik tinggi akan lebih mudah menyerap hal-hal baru dan berusaha untuk mampu menyelesaikan permasalahan dengan mengerahkan kemampuan berpikir kritisnya, sedangkan siswa dengan motivasi intrinsik rendah hanya mengikuti pembelajaran sekedarnya saja. Sejalan dengan penelitian yang dilakukan oleh pustaka [I3] yang mengemukakan bahwa peningkatan berpikir kritis juga dipengaruhi oleh tingkat motivasi intrinsik yang dimiliki siswa.

\section{Kesimpulan}

Berdasarkan data hasil penelitian dan pembahasan, dapat disimpulkan bahwa: (I) Pembelajaran dengan pendekatan pembelajaran STEM dapat meningkatkan kemampuan berpikir kritis siswa secara signifikan dengan taraf kepercayaan $95 \%$ dan nilai $N$-gain sebesar 0,63 dengan kategori sedang. (2) Peningkatan setiap indikator kemampuan berpikir kritis berbeda-beda. Peningkatan indikator tertinggi terdapat pada indikator memberikan pendapat dan kesimpulan awal, sedangkan peningkatan indikator terendah terdapat pada indikator menarik kesimpulan atau mengatur strategi dan taktik. (3) Hasil belajar dengan menerapkan pendekatan pembelajaran STEM pada kemampuan berpikir kritis lebih baik dibandingkan dengan menerapkan pendekatan pembelajaran konvensional.

\section{Kepustakaan}

[I] Permendikbud nomor 65, Standar Proses Pendidikan Dasar dan Menengah. Jakarta, Menteri Pendidikan dan Kebudayaan Indonesia, 2013.

[2] Septiani, A., Penerapan Asesmen Kinerja dalam Pendekatan STEM (Sains, Teknologi, Engineering, Matematika) untuk Mengungkap Keterampilan Proses Sains, Seminar Nasional Pendidikan dan Saintek Isu-isu Kontemporer Sains, Lingkungan, dan Inovasi Pembelajarannya, Universitas Pendidikan Indonesia, Bandung, 2016, pp 654-659.

[3] OECD, PISA 2015 Results in Focus: What 15-year-olds know and what they can do with what they know, 20I6. [Online], (http://www.oecd.org/pisa/keyfindings/pisa-2016-resultsoverview.pdf), diakses 27 Oktober 2017.

[4] TIMSS, International Result in Since. International Study Center, 20I5, pp. I-256. 
Implementasi pendekatan pembelajaran STEM untuk meningkatkan kemampuan berpikir kritis siswa SMA pada materi gelombang bunyi

[5] Redhana, I. W., Pengaruh Model Pembelajaran Berbasis Peta Argumen terhadap Keterampilan Berpikir Kritis Siswa pada Topik Laju Reaksi, Jurnal Pendidikan dan Pengajaran, Jilid 43, 20I0, pp. I4I-I48. (Online), (https://ejournal.undiksha.ac.id/ index.php/JPP/article/view/I72I), diakses September 2017.

[6] Permanasari, A., STEM Education : Inovasi dalam Pembelajatan Sains, Seminar Nasional Pendidikan Sains : Peningkatan Kualitas Pembelajaran Sains dan Kompetensi Guru Melalui Penelitian dan Pengembangan dalam Menghadapi Tantangan Abad-2I, Universitas Pendidikan Indonesia, Bandung, 2016, pp. 24-3I.

[7] Ennies, R. H., Critical Thinking : Reflection and Perspective Part I, Assessing Critical Thinking about Values: A QuasiExperimental Study: ResearchGate, 1996, pp. 4-17. [Online], (https://www.researchgate.net/publication/225026402_Asses sing_Critical_Thinking_about_Values_A_QuasiExperimental_ Study), diakses September 2017.

[8] Gonzalez, H. B. dan Kuenzi, J. J., Science, Technology, Engineering, and Mathematics (STEM) Education: A Primer. Congressional Research Service, 2012, pp. I-27. [Online], (https://fas.org/sgp/crs/misc/R42642.pdf), diakses September 2017.

[9] Lou, S.J., Shih, R.C., Diez, C.R., dan Tseng, K.H., The Impact of Problem Based Learning Strategies on STEM Knowledge Integration and Attitudie, an Exploratory Study Among Female Taiwanese Senior High School Students, International Journal of Thechnology and Design Education: Springer, 201I, pp. 195-215. [Online], (https://www.springer professional.de/en/the-impact-of-problem-based-learningstrategies-on-stem-knowledg/5490704), diakses September 2017.

[10] Asmuniv, Pendekatan Terpadu Pendidikan STEM Upaya Mempersiapkan Sumber Daya Manusia Indonesia Yang Memiliki Pengetahuan Interdisipliner dalam Menyosong Kebutuhan Bidang Karir Pekerjaan Masyarakat Ekonomi ASEAN (MEA), 2015.2 (http://www.vedcmalang.com/pppptkboemlg/index. $\mathrm{php} /$ menuutama/listrikelectro/I507-asv9), diakses I2 September 2017.

[II] Roberts, A. dan Cantu, D., Applying STEM Instructional Strategies to Design and Technology Curriculum. USA : Departement of STEM Education and Professional Studies Old Dominion University, 2012, pp. IIO-II8. [Online], (http: $/ /$ www.ep.liu.se $/$ ecp/article.asp?issue $=073 \&$ volume $=\&$ ar ticle $=013)$, diakses Oktober 2017.

[12] Morrison, J. S., TIES STEM Education Monograph Series Attributes of STEM Education. Washington, D.C., National Academy of Engineering, 2005, pp. I-7.

[13] Reta, I. K., Pengaruh Model Pembelajaran Berbasis Masalah Terhadap Keterampilan Berpikir Kritis Ditinjau dari Gaya Kognitif Siswa, Jurnal Penelitian Pascasarjana Undiksha, 2012, pp. I-IO. (Online), (https://media.neliti.com/media/publications/I20 228-IDpengaruh-model-pembelajaran-berbasis-mas.pdf), diakses Oktober 2017.

[14] Pratamawati, A.P., Prasetyo, Z. K. dan Satriana, A., Pengaruh Problem Based Learning (PBL) Terhadap Kemampuan Berpikir Kritis dan Problem Solving Siswa MAN I Yogyakarta I, Jurnal Pendidikan Fisika, Vol. 6, no. I, 2017, pp. I-8.

[15] Yuan, H., Kunaviktikul, W., Klunklin, A., dan Williams, B.A., Promoting Critical Thinking Skill through Problem Based Learning. CMU, Journal of Soc. Sci. And Human, Vol. 2, no. 2, 2008, pp. 85-100.

[16] Akinaglu, O. dan Ruhan, R. O., The effects of problem based active learning of student' academic achievement, attitude and concept learning, Eurasia Journal of Mathematics, Science \& Technology Education, Vol. 3, no. I, 2007, pp. 7I-8I.
[17] Pratiwi, U. dan Faisha, E.F., Pengembangan Instrumen Penilaian HOTS Berbasis Kurikulum 2013 Terhadap Sikap Disiplin, Jurnal Penelitian dan Pembelajaran IPA, Vol. I, no. I, 2015, pp. I23-I42.

[18] Rosnawati, R., Enam Tahapan Aktivitas dalam Pembelajaran Matematika untuk Mendayagunakan Berpikir Tingkat Tinggi Siswa. Makalah disajikan dalam Seminar Nasional Revitalisasi MIPA dan Pendidikan MIPA dalam rangka Penguasaan Kapasitas Kelembagaan dan Profesionalisme Menuju WCU, Universitas Negeri Yogyakarta, Yogyakarta, 2012. (Online), (http://staff.uny.ac.id), diakses I2 September 2017.

[19] Birgili, B., Creative and Critical Thinking Skills in Problembased Learning Environments, Journal of Gifted Education and Creativity, Vo. 2, no. 2, 2015, pp. 7I-80.

[20] Rahayuni, G., Hubungan Keterampilan Berpikir Kritis dan Literasi Sains pada Pembelajaran IPA Terpadu dengan Model PBM dan STM, Jurnal Penelitian dan Pembelajaran IPA, Vol. 2, no. 2, 20I6, pp. I3I-I46.

[2I] Yogantari, P., Yulianti, L., dan Suyudi, A., Pengaruh Model Integrative Learning Terhadap Kemampuan Berpikir Kritis Siswa pada Mata Pelajaran Fisika Kelas X MIA (matematika dan Ilmu-ilmu Alam) SMAN 3 Malang, Jurnal Online Pendidikan Fisika Universitas Malang, Vol. 2, no. I, 20I4, pp I-7.

[22] Nurasiah, R. F., Siahaan, P., Samsudin, A. \& Suhendi, E., Peningkatan kemampuan Berpikir Kritis Siswa SMP melalui Pembelajaran Berbasis Multimedia Komputer pada Materi Alat Optik, Seminar Nasional Fisika (SINAFI), 2015, pp. 169-I73. (Online), (https://www.researchgate.net/publication/306I I 8299), diakses September 2017.

[23] Fraenkel, J. R. dan Wallen, E. W., How To Design And Evaluate Research In Education. McGraw Hill Companies, New York, 2009.

[24] Hake, R. R., Relationship of Individual Student Normalized Learning Gains in Mechanics with Gender, High-School Physics, and Pretest Scores on Mathematics and Spatial Visualization Physics Education Research Conference; Boise, Idaho, 2002. [Online] (http://www.physics.indiana.edu/-hake) diunduh pada 18 Oktober 2017.

[25] Arikunto, S., Dasar-dasar Evaluasi Pendidikan Edisi 2, Jakarta, Bumi Aksara, 2012, pp. 320.

[26] Nazir, M., Metode Penelitian, Jakarta, Ghalia Indonesia, 2003, pp. 403.

[27] Nava, Thifli.N.S. 2015. Sumber Belajar IPA Online. (Online), (https; \thiflihabibi.wordpress.com), diakses pada I2 September 2017.

[28] Deanca, Fahrul. 20I4. Pasang Klakson FIAMM di NVL. (Online). (https: \\fachruldeanca.wordpress.com), diakses I2 September 2017.

[29] Anonim. 2014. Bagaimana Cara Kerja Sonar. (Online), (https: \\sainshack.wordpress.com), diakses pada I2 September 2017. 